${ }^{1}$ Centro de Educación Médica y Ciencias de la Salud, Facultad de Medicina, Pontificia Universidad Católica de Chile.Santiago, Chile.

${ }^{2}$ Programa de Bienestar y Liderazgo, Facultad de Medicina, Pontificia Universidad Católica de Chile.Santiago, Chile.

${ }^{3}$ Departamento de Nutrición Diabetes y Metabolismo, Facultad de Medicina, Pontificia Universidad Católica de Chile. Santiago, Chile.

${ }^{4}$ Dirección de Pregrado, Escuela de Medicina, Pontificia Universidad Católica de Chile. Santiago, Chile. aPsicóloga. bSociólogo. Ingeniera civil. dBioquímica. ephD.

Trabajo financiado por proyectos CONICYT-ANID, FONDECYT grants 1150340 y 1190232 .

Los autores declaran no tener conflictos de interés.

Recibido el 24 de diciembre de 2020, aceptado el 13 de abril de 2021.

Corresponding author: Marcela Bitran PhD, Centro de Educación Médica y Ciencias de la Salud, Facultad de Medicina, Pontificia Universidad Católica de Chile. Diagonal Paraguay 362. Santiago, Chile. mbitran@med.puc.cl

\section{Reduced burnout and higher mindfulness in medical students after a self-care program during the COVID-19 pandemic}

\author{
DENISSE ZÚÑIGA ${ }^{1, \mathrm{a}}$, MANUEL TORRES-SAHLI ${ }^{1, \mathrm{~b}}$, \\ PÍA NITSCHE ${ }^{2}$, GUADALUPE ECHEVERRÍA ${ }^{2,3, c}$, NURIA PEDRALS ${ }^{2,3, a}$, \\ BRUNO GRASSI ${ }^{3}$, MARCELA CISTERNAS ${ }^{4}$, \\ ATTILIO RIGOTTI ${ }^{2,3}$, MARCELA BITRAN ${ }^{1, \mathrm{~d}, \mathrm{e}}$
}

\begin{abstract}
Background: Medical students experience high levels of psychological stress during clinical training. However, most medical curricula do not teach self-care skills. The COVID-19 pandemic has disrupted medical education causing increased distress among students. Aim: To report the implementation and impact of an eight-week multifaceted mindfulness-based self-care program on medical students' distress and well-being during the COVID-19 pandemic. Material and Methods: One hundred twenty-three fourth-year medical students attended the program as part of a mandatory course from April to May 2020, during the rising phase of COVID-19 in Chile. They were evaluated using validated tests before and immediately after the program. The measures included burnout, dispositional mindfulness, perceived stress, traumatic stress reactions, general well-being, resilience, and stress coping strategies. Results: Burnout prevalence decreased from $48 \%$ to $24 \%$, whereas students with high dispositional mindfulness increased from $25 \%$ to $44 \%$. Burnout reduction was mostly due to decreased emotional exhaustion. Additionally, students reported lower levels of stress, self-blaming, and traumatic stress reactions alongside an increased use of active coping strategies and resilience levels after the program. Conclusions: A formal educational intervention, teaching self-awareness and self-regulation skills can help reduce medical students' distress and promote their well-being even amidst a pandemic.
\end{abstract}

(Rev Med Chile 2021; 149: 846-855)

Key words: COVID-19; Mindfulness; Self Care; Students, Medical.

\section{Reducción del agotamiento en estudiantes de medicina mediante auto-cuidado durante la pandemia COVID-19}

Antecedentes: Los estudiantes de medicina experimentan altos niveles de estrés y burnout durante la formación clínica. Sin embargo, la mayoría de los planes de estudios médicos no enseñan habilidades de autocuidado. La pandemia de COVID-19 ha conmocionado la educación médica provocando mayor 
distrés entre los estudiantes. Objetivo: Informar sobre la implementación y el impacto de un programa multifacético de autocuidado -basado en mindfulness (atención consciente)- sobre el distrés y el bienestar de los estudiantes de medicina durante la pandemia de COVID-19. Material y Métodos: Ciento veintitrés estudiantes de medicina de cuarto año asistieron al programa como parte de un curso obligatorio de abril a mayo de 2020, durante la fase ascendente de COVID-19 en Chile. Fueron evaluados mediante pruebas validadas antes e inmediatamente después del programa. Las medidas incluyeron burnout, mindfulness disposicional, estrés percibido, reacciones de estrés traumático, bienestar general, resiliencia y estrategias de afrontamiento del estrés. Resultados: La prevalencia del burnout disminuyó del $48 \%$ al 24\%, mientras que los estudiantes con alto mindfulness aumentaron del $25 \%$ al $44 \%$. La reducción del burnout se debió principalmente a la disminución del agotamiento emocional. Además, los estudiantes informaron niveles más bajos de estrés, autoinculpación $y$ reacciones de estrés traumático junto con un mayor uso de estrategias activas de afrontamiento y mayores niveles de resiliencia, después del programa de autocuidado. Conclusiones: Una intervención educativa formal que enseñe habilidades de autoconciencia y autorregulación puede ayudar a reducir el burnout de los estudiantes de medicina y promover su bienestar incluso en medio de una pandemia.

Palabras clave: Atención Plena; Autocuidado; COVID-19; Estudiantes de Medicina.

$\mathrm{M}$ edical students worldwide experience high levels of psychological distress during the clinical training ${ }^{1-10}$. Indeed, our survey of 1,170 Chilean medical students in 2015 revealed that one in every two students experienced burnout (Bitran et al., 2020, under revision).

Burnout is a work-related syndrome that affects individuals subjected to chronic emotional stressors and high professional demands (https:// www.who.int/news/item/28-05-2019). It is characterized by exhaustion of physical and emotional resources, development of a cynical attitude toward work (or training), and a reduced sense of self-efficacy ${ }^{11,12}$. Serious personal, academic, and professional consequences result from this chronic erosion of well-being, which includes a higher prevalence of depression and suicidal ideation, unprofessional behaviors, and increased academic dropout among medical students ${ }^{1,13-15}$.

The COVID-19 pandemic is posing additional challenges to medical education ${ }^{16,17}$ and to medical students' mental health ${ }^{18,19}$. The replacement of clinical face-to-face activities with distance learning has brought significant stress and anxiety for trainees who worry about achieving clinical competencies and graduating ${ }^{16,20}$. An increasing number of publications are documenting the negative impact of the COVID-19 pandemic on students' mental health ${ }^{18,21-24}$. In these unprecedented times, educating students about self-care has become imperative to help them deal with the adverse effects of the pandemic and the challenges of becoming a doctor ${ }^{19}$.

Both organization-focused and individual-oriented interventions are required to reduce burnout and promote sustainable changes in well-being ${ }^{25-27}$. At the individual level, successful interventions have combined various activities (e.g., mindfulness training, reflective journaling, stress-reduction techniques) to develop self-awareness and self-regulatory skills ${ }^{27-29}$. Evidence is particularly robust for mindfulness-based interventions $(\mathrm{MBI})^{27,30-32}$, which teaches individuals to cultivate an "awareness that emerges through paying attention on purpose, in the present moment, and non-judgmentally to the unfolding of experience moment by moment"33.

This study reports the implementation of a multifaceted mindfulness-based self-care program in the core medical curriculum and documents the impact of this program on students' distress, dispositional mindfulness, and well-being. 


\section{Methods}

\section{Study design}

A non-experimental, pre- and post-observational cohort study followed the class of fourth year students at the Universidad Católica de Chile Medical School ( $\mathrm{n}=123)$. Students $(\mathrm{n}=123 ; 48.8 \%$ women) were requested to complete an online survey before and after the program, i.e., nine weeks later. 102 students (82.9\%) completed the survey at both time points.

\section{Educational setting}

The undergraduate medical program at the Universidad Católica de Chile Medical School comprises a six year Flexnerian-type curriculum ${ }^{34}$. Basic sciences are taught in the first two years with a preclinical transition through years 2 and 3 , and clinical training begins with year 4 . The second half of year 5 and year 6 corresponds to fully supervised practice in hospital and ambulatory settings.

\section{Educational program: "Self-care, an essential competence of today's physician"}

The curriculum was developed by a team of well-being researchers $(\mathrm{MB}, \mathrm{AR}, \mathrm{NP}, \mathrm{DZ}, \mathrm{GE}$, $\mathrm{PN}$ ) according to Kern's six-step mode ${ }^{35}$. The topics included burnout, mindfulness, well-being scientific models, energy and time management, emotional regulation, cognitive distortions (rumination), positive relationships, compassion and self-compassion, and reconnecting with purpose and meaning.

The program included three synchronous remote sessions and five online self-paced modules. Remote sessions held via Zoom included large and small (7-10 students/tutor) group activities and were facilitated by clinical tutors specially trained for this purpose.

Students were required to complete the online activities, attend the synchronous sessions, and write four two-week journals registering their emotions, ruminations, positive relationships, and lifestyle habits. At the end of each journal entry, students were required to write a reflection on their self-monitoring experience. The clinical tutors provided one-on-one feedback on these reflective assignments ${ }^{36}$.

The end of the program was postponed due to an unscheduled mandatory one-week break. This measure was intended to ease the pressure on undergraduate students, who had been attending online lectures for 8 hours daily while under lockdown during the COVID-19 pandemic.

\section{Ethical approval}

The Scientific Committee of Ethics in Health Sciences of the Pontificia Universidad Católica de Chile reviewed and approved this study. Data were stored and handled by two researchers (MB, MT) after anonymization before any aggregate analysis.

\section{Variables and instruments}

We used validated Spanish (Chilean whenever possible) versions of the following self-report instruments:

Burnout was measured using the Maslach Burnout Inventory questionnaire (MBI-HSS) 37,38 . It comprises 22 items rated on a seven-point $\mathrm{Li}^{-}$ kert-type scale (0-6) measuring three dimensions: emotional exhaustion (EE), depersonalization (DP), and personal accomplishment (PA). To determine the burnout condition, we used cut-off points defined by receiver operating characteristic curves analysis obtained from a large sample of Chilean medical students. Burnt-out students presented EE scores $\geq 36$ or depersonalization (DP) scores $\geq 11$.

Perceived stress was measured using the Perceived Stress Scale (PSS) ${ }^{39}$, a 10-item questionnaire rated on a five-point frequency scale that measures the degree to which participants appraised situations during the last month in their life as stressful.

Traumatic stress reaction was measured using the Revised Impact of Event Scale (IES-R) ${ }^{40}$. It contains 22 items rated on a five-point Likert-type scale and measures the intensity with which the respondent has experienced specified difficulties during the past seven days related to a traumatic event (in this case, the outburst of the COVID-19 pandemic).

Coping strategies were measured using the Brief-COPE (Coping Orientation to Problems Experienced) questionnaire ${ }^{41}$. It contains 28 items rated on a 4-point scale and measures the frequency with which respondents use the 14 different strategies to cope with life challenges.

Dispositional mindfulness was measured using the Mindful Attention Awareness Scale 
(MAAS), a 14-item questionnaire rated on a sixpoint scale that measures the level of individuals' awareness of sensations, emotions, and thoughts in the present moment ${ }^{42,43}$.

Positive mental health was measured using the Mental Health Continuum Short-Form (MHC$\mathrm{SF})^{44,45}$, a 14 -item questionnaire rated on a sixpoint scale assessing the emotional, social, and psychological dimensions of well-being.

Resilience was measured using the 10-item Connor-Davidson Resilience Scale (CD-RISC) rated on a five-point scale, which measures the ability to adapt to change ${ }^{46}$.

\section{Data and statistical analyses}

Factor analysis and indices of reliability. We analyzed the data within a Confirmatory Factor Analysis (CFA) framework to determine the instruments' reliability. We used Kaiser-Meyer-Olkin measure of sample adequacy (KMO-MSA) and Bartlett's Sphericity test. Multivariate normality was not assumed; therefore, we used an unweighted least squares estimator with mean and variance adjusted (USLMV) for CFA.

To study the reliability of aggregate or composite scores (e.g., sum, average), McDonald's $\omega$ was reported alongside Cronbach's $\alpha$ coefficients because $\omega$ provided better estimates of the composite scores' reliability ${ }^{47}$.

Changes in students' distributions. We used $\chi^{2}$ tests to compare the proportion of students in burnout and dispositional mindfulness categories before and after the educational program.

Comparison of means according to sex and time. We performed a two-way repeated-measures ANOVA to compare the average scores of men and women, changes in scores between $\mathrm{T} 1$ and $\mathrm{T} 2$, and the interaction between sex and time.

Latent change scores. Within a Structural Equation Modeling framework, we estimated a Latent Change Score Model (LCSM) ${ }^{48}$. This model allows the calculation of the difference or changes in variables based only on the shared variance of observed scores, which affords increased reliability in the analyses of both variables' temporal changes and the estimation of these changes' standardized size, used for comparison purposes.

\section{Results}

\section{Factor analysis and reliability}

The data for all instruments, except the COPE scale, met the assumptions for assessing their factor structure, i.e., sample adequacy (KMOMSA > .50) and absence of sphericity (Bartlett's Sphericity test, $p<.001$ ).

Regarding the Brief-COPE, only items with commonality over 0.5 were included in the analyses. Additionally, we merged factors with a correlation $\geq .80$, and retained those factors with two items only if the loadings were $\geq .70$. Applying these criteria resulted in an abbreviated version of the instrument that retained 6 of the 14 strategies of the original questionnaire.

Overall, the reliability indices for the scores of all instruments were good $(\alpha=.75-.94$, $\omega=.67-.92$ ). Burnout variables with lowest reliability were personal accomplishment $(\alpha=.76$, $\omega=.67)$ and depersonalization $(\alpha=.75, \omega=.69)$ (Table 1).

\section{Table 1. Reliability indices of psychological} assessment instruments

\begin{tabular}{|lcc|}
\hline Variable & $\begin{array}{c}\text { Cronbach's } \\
\text { McDonald's }\end{array}$ \\
Burnout (MBI) & $\boldsymbol{\omega}$ \\
Emotional exhaustion & .91 & .87 \\
Depersonalization & .75 & .69 \\
Personal accomplishment & .76 & .67 \\
Stress (PSS) & .94 & .92 \\
General Well-being & .94 & .84 \\
(MHC-SF) & .94 \\
Dispositional Mindfulness & .90 & .73 \\
(MAAS) & & \\
Resilience (CD-RISC) & .91 & .88 \\
Stress Coping Strategies (COPE) & & \\
Support-seeking & .93 & .77 \\
Active coping & .86 & .70 \\
Reappraisal & .84 & .77 \\
Disconnection & .82 & .73 \\
Denial & .89 & .80 \\
Self-blaming & .89 & .83 \\
Traumatic Stress (EIE) & .94 & .86 \\
\hline
\end{tabular}




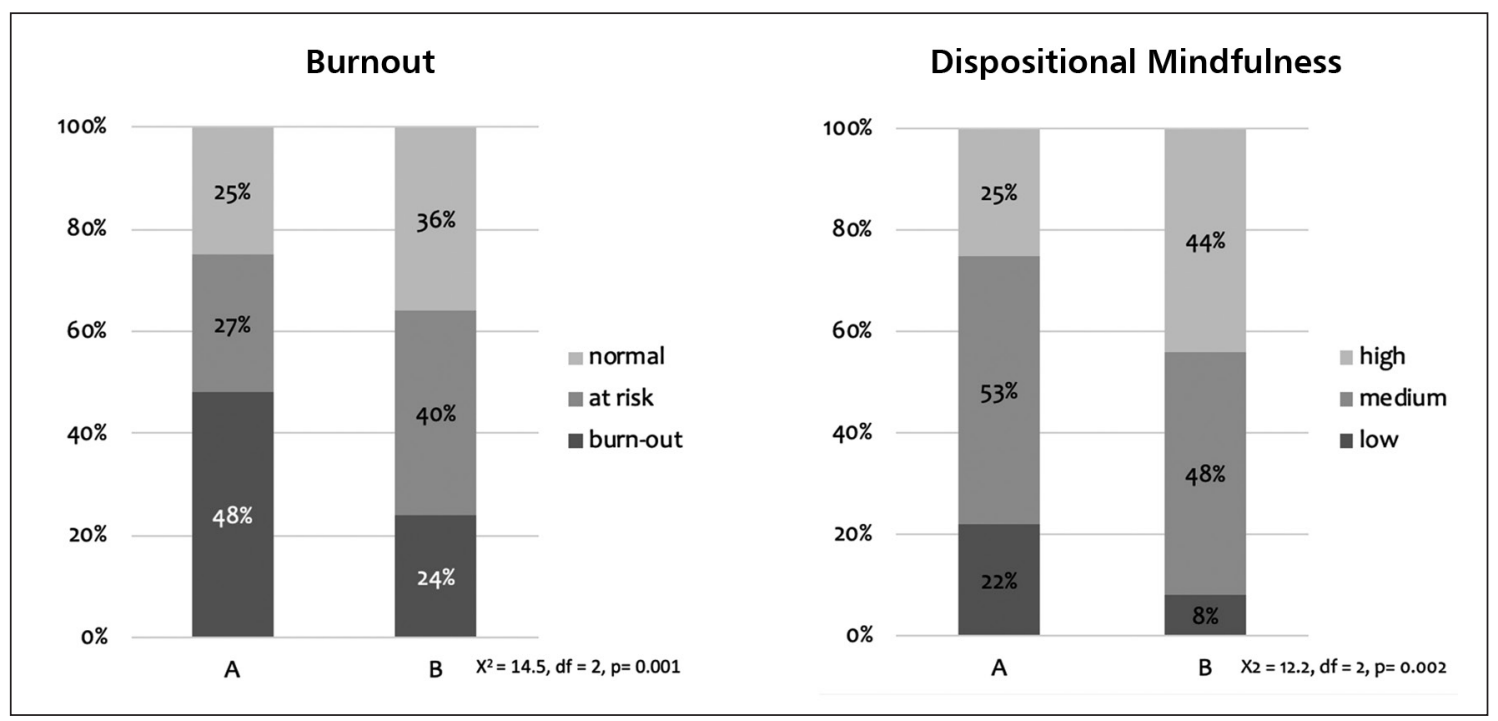

Figure 1. Burnout prevalence and mindfulness levels of medical students before (A) and after (B) participating in the self-care educational program.

\section{Changes in burnout prevalence and mindfulness after the educational program}

Burnout prevalence decreased significantly after the program: from $48 \%$ immediately before beginning the program to $24 \%$ nine weeks later (Figure $1 ; \chi^{2}=14.5, \mathrm{df}=2, p=0.001$ ). Across this period, a concomitant increase in the proportion of students with high dispositional mindfulness (MAAS score $\geq 4)$ from $25 \%$ to $44 \%\left(\chi^{2}=12.2\right.$, $\mathrm{df}=2, p=0.002)$ was detected. No significant differences associated with students' sex were found in these measures in either T1 or T2 $\left(\chi^{2}>0.5\right)$.

\section{Time and sex-related changes}

Within a week after the program, students reported a) decreased levels of emotional exhaustion, depersonalization, stress, traumatic stress, and self-blaming, and b) increased scores of mindfulness, well-being, resilience, active coping, support-seeking, and positive reframing. No significant changes were found in the scores of personal accomplishment, denial, or behavioral disengagements (Table 2).

Women reported lower levels of dispositional mindfulness and depersonalization, and higher levels of perceived stress and traumatic stress reactions. Resilience showed a time by sex interaction: only women reported an increase in resilience levels (Table 2), and the difference between men and women was statistically significant only in $\mathrm{T} 1$.

\section{Changes in standardized latent scores}

The analysis of the standardized latent change scores $(95 \%$ CI) for all variables between pre- and post-program measurements (Figure 2) confirmed the results obtained by ANOVA and revealed that emotional exhaustion presented the largest drop (-.66; 95\% CI: -.85 - -.48), whereas dispositional mindfulness showed the biggest increase (.39; $95 \%$ CI: $+.23-+.56)$.

\section{Discussion}

This study reports a decrease in medical students' burnout prevalence and an increase in their dispositional mindfulness (DM) after attending the program "Self-care, an essential competence of today's physician," an educational intervention incorporated in the core medical curriculum. Burnt-out students decreased from $48 \%$ at baseline to $24 \%$ after the program, mostly due to a decrease in emotional exhaustion (EE). Students also reported lower levels of stress and self-blaming, and less traumatic stress reactions together 
Table 2. Mean values of psychosocial variables before (T1) and after (T2) the self-care program according to sex

\begin{tabular}{|c|c|c|c|c|c|c|c|c|c|}
\hline Measurements & Males & $\begin{array}{c}\text { T1 } \\
\text { Females }\end{array}$ & Total & Males & $\begin{array}{c}\text { T2 } \\
\text { Females }\end{array}$ & Total & $\begin{array}{c}\text { sex } \\
\text { p-value }\end{array}$ & $\begin{array}{l}\text { ANOVA } \\
\text { time } \\
\text { p-value }\end{array}$ & $\begin{array}{c}\text { Interaction } \\
\text { p-value }\end{array}$ \\
\hline \multicolumn{10}{|l|}{ Burnout } \\
\hline Emotional exhaustion & 29.08 & 32.69 & 30.92 & 21.54 & 24.19 & 22.89 & .104 & $<.001 * * *$ & .623 \\
\hline Depersonalisation & 9.02 & 6.79 & 7.88 & 7.86 & 5.37 & 6.59 & $.008^{* *}$ & $.015^{*}$ & .800 \\
\hline Personal accomplishment & 32.38 & 32.25 & 32.31 & 33.36 & 33.58 & 33.47 & .970 & .056 & .772 \\
\hline Stress & 17.74 & 22.06 & 19.94 & 14.32 & 15.9 & 15.13 & $.044^{*}$ & $<.001^{* * *}$ & .087 \\
\hline Traumatic Stress & 20.5 & 26.98 & 23.8 & 18.54 & 23.11 & 20.87 & $.012^{*}$ & $.020 *$ & .439 \\
\hline Dispositional Mindfulness & 3.96 & 3.49 & 3.72 & 4.32 & 4.04 & 4.18 & $.025^{*}$ & $<.001^{* * *}$ & .285 \\
\hline General Well-being & 43.12 & 42.65 & 42.88 & 45.72 & 47.25 & 46.5 & .836 & $.001 * *$ & .363 \\
\hline Resilience & 29.36 & 26.14 & 27.72 & 30.3 & 29.21 & 29.75 & .090 & $<.001^{* * *}$ & $.037^{*}$ \\
\hline \multicolumn{10}{|l|}{ Coping Strategies } \\
\hline Active coping & 12.6 & 12.25 & 12.42 & 13.38 & 13.31 & 13.34 & .588 & $<.001 * * *$ & .515 \\
\hline Support-seeking & 9.8 & 12.08 & 10.96 & 10.4 & 12.88 & 11.67 & $<.001 * * *$ & $.004^{* *}$ & .668 \\
\hline Positive reframing & 5.74 & 5.38 & 5.56 & 6.26 & 5.75 & 6 & .076 & $.003^{* *}$ & .590 \\
\hline Denial & 2.6 & 2.94 & 2.77 & 2.68 & 2.83 & 2.75 & .249 & .888 & .439 \\
\hline
\end{tabular}

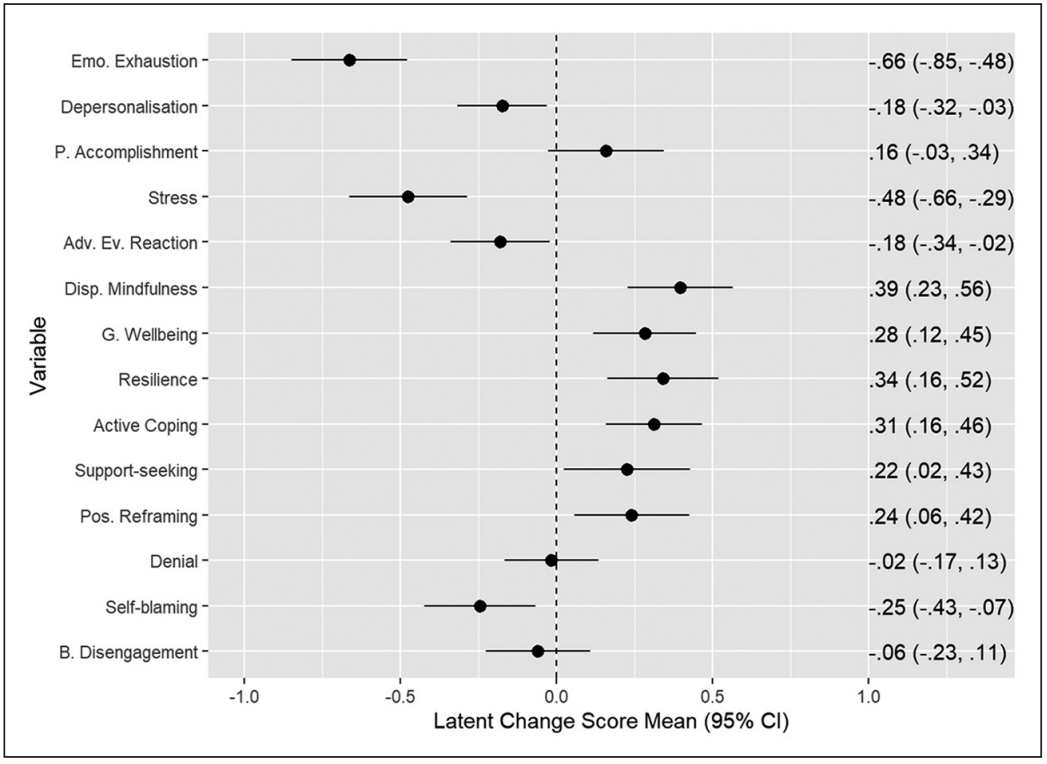

Figure 2. Standardized latent change scores between pre- and post-program measurements. with an increased use of active coping strategies and higher resilience levels after the program.

Gender differences detected in this study are consistent with previous literature: female medical students reported more stress and emotional exhaustion $^{49-52}$, less depersonalization ${ }^{53,54}$, and lower levels of DM than male students ${ }^{55}$.
A recent systematic review of MBI on medical students ${ }^{30}$ showed that $57 \%$ of studies measuring stress demonstrated significant reductions in this variable whereas only one of three studies reporting burnout showed a reduction in EE. After a four-week elective course on Mindful Medical Practice, Canadian medical students' EE levels 
decreased by $14.4 \%{ }^{56}$. Our students' $25 \%$ reduction in EE compares favorably not only with the aforementioned study but also with a meta-analysis of interventions on physician burnout ${ }^{31}$. The relevance of the present findings is underscored by previous literature showing that similar reductions in EE levels are associated with a decrease in the residents' perceived medical errors ${ }^{15}$.

The increase in DM seen in this study after the self-care program is consistent with results of previous meta-analyses showing that MBIs result in DM increases of similar magnitudes ${ }^{57}$. Interestingly, DM correlates with beneficial changes in mental health ${ }^{58}$. For example, individuals with higher DM are less likely to get trapped in negative cognitive processes (e.g., rumination) that increase the risk of emotional disorders ${ }^{59}$. Furthermore, DM was found to moderate the inverse relationship between several dimensions of self-care and psychological distress ${ }^{55}$. Therefore, it is conceivable that, in this study, DM could have had a mediating effect between the self-care training and the observed increase in students' well-being.

The positive changes observed in this study are more valuable because they occurred in the context of a major pandemic. One would have expected that the uncertainty and confinement brought about by COVID-19 would have increased students' distress and difficulties in emotional regulation. Conversely, in their reflective essays, students conveyed a sense of improvement in well-being and enhanced resourcefulness to face the academic workload and the challenges posed by the COVID-19 pandemic ${ }^{36}$.

We are acutely aware that causal attributions cannot be made regarding the present findings on the educational program in the absence of a control group. Despite this limitation, we opted for an uncontrolled pre-post design because we deemed it unethical to withhold the access to this self-care program from some students.

The decrease in students' stress and emotional exhaustion could be partly explained by the one-week study break before ending the intervention. However, the enhanced mindfulness and resilience, as well as the increased use of active coping skills, cannot be as easily explained by this variable. These were skills intently targeted by the educational program; thus, their improvement likely relates to students' engagement in the edu- cational activities.

Our program is one of the few comprehensive and integrated student well-being programs built into the core curriculum ${ }^{60}$. At the Monash University, a course called the Health Enhancement Program is taught to first year students ${ }^{61}$, while in the Rochester University, the Mindful Practice Program is taught primarily in the third year ${ }^{62}$. Generally, the results indicate that such programs are beneficial in terms of reducing students' negative emotions and stress, and enhancing their mindfulness, empathy, and self-compassion ${ }^{63}$.

\section{Strengths}

This study has several strengths. First, the incorporation of the program in the core curriculum ensured that the intervention reached the whole class. Many excellent efforts invested in extracurricular initiatives have failed because elective activities have high attrition levels ${ }^{60}$. We hope that the formal character of this curricular intervention and the participation of clinical tutors sent a powerful message to the educational community about the importance of self-care as a medical competence. Second, we used several validated scales to probe a broad spectrum of psychosocial aspects that provided a multifaceted picture of the real ill- and well-being status of students.

\section{Limitations}

This study has several limitations. First, it lacks a control group, which precludes the inference of causal relationships. Second, it was implemented in an extraordinary context of one of the most dangerous pandemics of the last century. This situation likely affects extrapolation and generalizability of this study results to 'normal' times. Additionally, this is a single institution study. However, beginning in 2021, this program will be taught in seven additional Chilean medical schools to assess its replicability.

\section{Conclusions and future directions}

Findings from this study suggest that a formal multifaceted mindfulness-based self-care program incorporated in the core curriculum can help prevent medical students' distress and promote their well-being, even amidst the COVID-19 pandemic. 
Future efforts should focus on identifying crucial aspects of the intervention and the underlying psychosocial mediators and mechanisms.

In the near future, this type of program will most likely be required by the accreditation agencies in undergraduate education, as is the case for graduate medical education in the United States (https://www.acgme.org/What-We-Do/Accreditation/Common-Program-Requirements) and Canada $^{63}$.

Acknowledgments: We are grateful to Dr. Alejandro Bruhn, Dra. Andrea Rioseco, Dra. Blanca Peñaloza, Dra. Constanza Caneo, Dra. Deidyland Arenas, Dra. Lorena Karsulovic, Dra. Lorena Salinas, Dr. Matías González, EU. Natalia Gana, Dr. Phillip Adwanter, Dr. Sebastián Irarrázaval, Dra. Sofía Basauri, and Dra. Valentina Serrano who participated as tutors of the program and to all the medical students for their openness to this program and commitment to their well-being.

\section{References}

1. Hope V, Henderson M. Medical student depression, anxiety and distress outside North America: a systematic review. Med Educ 2014;48:963-79. https://doi. org/10.1111/medu.12512.

2. Erschens R, Keifenheim KE, Herrmann-Werner A, Loda T, Schwille-Kiuntke J, Bugaj TJ, et al. Professional burnout among medical students: Systematic literature review and meta-analysis. Med Teach 2018:1-12. https:// doi.org/10.1080/0142159X.2018.1457213.

3. IsHak W, Nikravesh R, Lederer S, Perry R, Ogunyemi D, Bernstein C. Burnout in medical students: a systematic review. Clin Teach 2013;10:242-5. https://doi. org/10.1111/tct.12014.

4. Chunming WM, Harrison R, MacIntyre R, Travaglia J, Balasooriya C. Burnout in medical students: a systematic review of experiences in Chinese medical schools. BMC Med Educ 2017;17:217. https://doi.org/10.1186/s12909017-1064-3.

5. Youssef FF. Medical Student Stress, Burnout and Depression in Trinidad and Tobago. Acad Psychiatry 2016;40:69-75. https://doi.org/10.1007/s40596-0150468-9.

6. Bitran M, Zúñiga D, Pedrals N, Echeverría G, Vergara C, Rigotti A, et al. Burnout in students of health-care professions. Risk and protection factors. Rev Med Chile 2019;147:510-7. https://doi.org/10.4067/S0034-
98872019000400510.

7. Bitran M, González M, Nitsche P, Zúñiga D, Riquelme A. Concern for residents' wellbeing, an issue discussed at the latin american conference on resident education (LACRE) 2017. Rev Med Chile 2017;145. https://doi. org/10.4067/S0034-98872017001001330.

8. Alfaro-Toloza P, Olmos-De-Aguilera R, Fuentealba M, Céspedes-González E. Burnout Syndrome and Associated Factors in Medical Students From a Chilean Medicine School. CIMEL 2013;18:23-6.

9. Novoa-Sandoval P, Burgos-Muñoz RM, Zentner-Guevara JA, Toro-Huamanchumo CJ. Burnout en estudiantes de enfermería de una universidad peruana. Investig En Educ Médica 2017. https://doi.org/10.1016/j. riem.2017.05.001.

10. Pacheco JP, Giacomin HT, Tam WW, Ribeiro TB, Arab C, Bezerra IM, et al. Mental health problems among medical students in Brazil: a systematic review and meta-analysis. Rev Bras Psiquiatr 2017;39:369-78. https:// doi.org/10.1590/1516-4446-2017-2223.

11. Maslach C and Jackson S. the measurement of experienced burnout. J Ocupp Behav 1981;2:99-113. https://doi. org/10.1002/job.4030020205.

12. Maslach C, Leiter MP. New insights into burnout and health care: Strategies for improving civility and alleviating burnout. Med Teach 2017;39:160-3. https://doi.org/ 10.1080/0142159X.2016.1248918.

13. Jackson ER, Shanafelt TD, Hasan O, Satele DV, Dyrbye LN. Burnout and Alcohol Abuse/Dependence Among U.S. Medical Students. Acad Med 2016;91:1251-6. https://doi.org/10.1097/ACM. 0000000000001138.

14. Dyrbye LN, Thomas MR, Power DV, Durning S, Moutier C, Massie FS, et al. Burnout and Serious Thoughts of Dropping Out of Medical School: A Multi-Institutional Study. Acad Med 2010;85:94-102. https://doi. org/10.1097/ACM.0b013e3181c46aad.

15. West CP, Tan AD, Habermann TM, Sloan JA, Shanafelt TD. Association of Resident Fatigue and Distress With Perceived Medical Errors. JAMA 2009;302:1294. https:// doi.org/10.1001/jama.2009.1389.

16. Rose S. Medical Student Education in the Time of COVID-19. JAMA - J Am Med Assoc 2020;323:2131-2. https://doi.org/10.1001/jama.2020.5227.

17. Gibbs T. The COVID-19 pandemic: Provoking thought and encouraging change. Med Teach 2020;42:738-40. https://doi.org/10.1080/0142159X.2020.1775967.

18. Komer L. COVID-19 amongst the Pandemic of Medical Student Mental Health. Int J Med Students 2020;8:56-7. https://doi.org/10.5195/ijms.2020.501.

19. Chandratre S. Medical Students and COVID-19: Challenges and Supportive Strategies. J Med Educ 
Curric Dev 2020;7:238212052093505. https://doi. org/10.1177/2382120520935059.

20. Ballart MJ, González J, Vega D, Larraín S, Muñoz F, Pérez S, et al. Experiencia del internado de medicina durante la pandemia por COVID-19 Medical internship experience during the COVID-19 pandemic 2020:72-5. https://doi.org/10.11565/arsmed.v45i3.1725.

21. Lyons Z, Wilcox H, Leung L, Dearsley O. COVID-19 and the mental well-being of Australian medical students: impact, concerns and coping strategies used. Australas Psychiatry 2020;28:649-52. https://doi. org/10.1177/1039856220947945.

22. Wenjun C, Ziwei F, Guoqiang H, Mei H, Xinrong X, Jiaxin D, et al. The psychological impact of the COVID-19 epidemic on college students in China. Psychiatry Res 2020;287:1-5.

23. Rao P, Diamond J, Korjian S, Martin L, Varghese M, Serfas JD, et al. The Impact of the COVID-19 Pandemic on Cardiovascular Fellows-in-Training: A National Survey. J Am Coll Cardiol 2020;76:871-5. https://doi. org/10.1016/j.jacc.2020.06.027.

24. Launer J. Burnout in the age of COVID-19. Postgrad Med J 2020;96:367-8. https://doi.org/10.1136/postgradmedj-2020-137980.

25. Shanafelt T, Trockel M, Ripp J, Murphy M Lou, Sandborg C, Bohman B. Building a Program on Well-Being: Key Design Considerations to Meet the Unique Needs of Each Organization. Acad Med 2019;94:156-61. https:// doi.org/10.1097/ACM.0000000000002415.

26. Taking Action Against Clinician Burnout. 2019. https:// doi.org/10.17226/25521.

27. Shiralkar MT, Harris TB, Eddins-Folensbee FF, Coverdale JH. A Systematic Review of Stress-Management Programs for Medical Students. Acad Psychiatry 2013;37:158-64.

28. Grossman P, Niemann L, Schmidt S, Walach H. Mindfulness-based stress reduction and health benefits: A meta-analysis. J Psychosom Res 2004;57:35-43. https:// doi.org/10.1016/S0022-3999(03)00573-7.

29. Sharp M, Burkart KM. Trainee Wellness: Why It Matters, and How to Promote It. Ann Am Thorac Soc 2017;14:505-12. https://doi.org/10.1513/AnnalsATS.201612-1006PS.

30. Daya Z, Hearn JH. Mindfulness interventions in medical education: A systematic review of their impact on medical student stress, depression, fatigue and burnout. Med Teach 2018;40:146-53. https://doi.org/10.1080/014 2159X.2017.1394999.

31. West CP, Dyrbye LN, Erwin PJ, Shanafelt TD. Interventions to prevent and reduce physician burnout: a systematic review and meta-analysis. Lancet
2016;388:2272-81. https://doi.org/10.1016/S01406736(16)31279-X.

32. Scheepers RA, Emke H, Epstein RM, Lombarts KMJMH. The impact of mindfulness-based interventions on doctors' well-being and performance: A systematic review. Med Educ 2020;54:138-49. https://doi.org/10.1111/ medu.14020.

33. Kabat-Zinn J. Mindfulness-based interventions in context: Past, present, and future. Clin Psychol Sci Pract 2003;10:144-56. https://doi.org/10.1093/clipsy/bpg016.

34. Cisternas M, Rivera S, Sirhan M, Thone N, Valdés C, Pertuzé J, et al. Reforma curricular de la carrera de medicina de la pontificia universidad católica de Chile. Rev Med Chile 2016;144:102-7. https://doi.org/10.4067/ S0034-98872016000100013.

35. David K, Patricia T, Mark H. Curriculum Development for Medical Education.pdf 1998:1-23.

36. Nitsche P, Echeverría G, Pedrals N, Zúñiga D, Rigotti A, Bitran M. Autocuidado en Estudiantes. Resultados de un Programa Online. ARS Médica 2021 (accepted).

37. Olivares V, Jélvez C. Running Head: Síndrome de Quemarse por el Trabajo. Efectos de la Ambiguedad del Rol y la Autoeficacia sobre Síndrome de Quemarse por el Trabajo (burnout). Estudio Longitudinal en Profesionales de Administración y Servicios. Congr. Soc. «La Pers. en el Corazón del Desarro. Pontif. Univ. Católica Chile, 2012, p. 1-19.

38. Gil-Monte PR. Validez factorial de la adaptación al español del Maslach Burnout Inventory-General Survey. Salud Publica Mex 2002;44:33-40. https://doi.org/10.1590/ S0036-36342002000100005.

39. Pérez Díaz F, Cartes-Velásquez R. Stress and burnout in Dentistry students: a concerning problem in the professional formation. EDUMECENTRO 2015;7:179-90.

40. Caamaño LW, Fuentes DM, González LB, Melipillán RA, Sepúlveda MC, Valenzuela EG. Adaptación y validación de la versión chilena de la escala de impacto de evento-revisada (EIE-R). Rev Med Chile 2011;139:11638. https://doi.org/10.4067/S0034-98872011000900008.

41. Morán C, Landero R, González MT. COPE-28: Un análisis psicométrico de la versión en Español del brief COPE. Univ Psychol 2010;9:543-52.

42. Soler J, Tejedor R, Feliu-Soler A, Pascual J, Cebolla A, Soriano J, et al. Psychometric proprieties of Spanish version of Mindful Attention Awareness Scale (MAAS). Actas Españolas Psiquiatr., vol. 40, 2012, p. 19-26. https://doi.org/10.1063/1.4993410.

43. Brown KW, Ryan RM. The Benefits of Being Present: Mindfulness and Its Role in Psychological Well-Being. J Pers Soc Psychol 2003;84:822-48. https://doi. org/10.1037/0022-3514.84.4.822. 
44. Echeverría G, Torres M, Pedrals N, Padilla O, Rigotti A, Bitran M. Validation of a Spanish Version of the Mental Health Continuum-Short Form Questionnaire. Psicothema 2017;29:96-102. https://doi.org/10.7334/ psicothema2016.3.

45. Keyes C. Brief description of the mental health continuum short form (MHC-SF). Am J Public Health 2009. https://doi.org/10.2105/AJPH.2010.192245.

46. Houpy JC, Lee WW, Woodruff JN, Pincavage AT. Medical student resilience and stressful clinical events during clinical training. Med Educ Online 2017;22:1320187. https://doi.org/10.1080/10872981.2017.1320187.

47. Zinbarg RE, Revelle W, Yovel I. Estimating wh for structures containing two group factors: Perils and prospects. Appl Psychol Meas 2007;31:135-57. https:// doi.org/10.1177/0146621606291558.

48. Ghisletta P, McArdle JJ. Teacher's Corner: Latent Curve Models and Latent Change Score Models Estimated in R. Struct Equ Model 2012;19:651-82. https://doi.org/10 .1080/10705511.2012.713275.

49. Fares J, Saadeddin Z, Al Tabosh H, Aridi H, El Mouhayyar C, Koleilat MK, et al. Extracurricular activities associated with stress and burnout in preclinical medical students. J Epidemiol Glob Health 2016;6:177-85. https://doi.org/10.1016/J.JEGH.2015.10.003.

50. Dahlin ME, Joneborg N, Runeson B. Performance-based self-esteem and burnout in a cross-sectional study of medical students. Med Teach 2007;29:43-8. https://doi. org/10.1080/01421590601175309.

51. Amoafo E, Hanbali N, Patel A, Singh P. What are the significant factors associated with burnout in doctors? Occup Med (Lond) 2015;65:117-21. https://doi. org/10.1093/occmed/kqu144.

52. van Dijk I, Lucassen PLBJ, van Weel C, Speckens AEM. A cross-sectional examination of psychological distress, positive mental health and their predictors in medical students in their clinical clerkships. BMC Med Educ 2017;17:219. https://doi.org/10.1186/s12909-017-10358.

53. Lapinski J, Yost M, Sexton P, LaBaere RJ. Factors Modifying Burnout in Osteopathic Medical Students. Acad Psychiatry 2016;40:55-62. https://doi.org/10.1007/ s40596-015-0375-0.

54. Prins JT, Hoekstra-Weebers JEHM, Gazendam-Do- nofrio SM, Dillingh GS, Bakker AB, Huisman M, et al. Burnout and engagement among resident doctors in the Netherlands: A national study. Med Educ 2010;44:23647. https://doi.org/10.1111/j.1365-2923.2009.03590.x.

55. Slonim J, Kienhuis M, Di Benedetto M, Reece J. The relationships among self-care, dispositional mindfulness, and psychological distress in medical students. Med Educ Online 2015;20:27924. https://doi.org/10.3402/ meo.v20.27924.

56. Garneau K, Hutchinson T, Zhao Q, Dobkin P. Cultivating person-centered medicine in future physicians. Eur J Pers Centered Healthc 2013;1:468. https://doi. org/10.5750/ejpch.v1i2.688.

57. Quaglia JT, Braun SE, Freeman SP, McDaniel MA, Brown KW. Meta-Analytic Evidence for Effects of Mindfulness Training on Dimensions of Self-Reported Dispositional Mindfulness. Psychol Assess 2016;28:80318. https://doi.org/10.1037/pas0000268.

58. Brown KW, Ryan RM, Creswell JD. Mindfulness: Theoretical foundations and evidence for its salutary effects. Psychol Inq 2007;18:211-37. https:/doi. org/10.1080/10478400701598298.

59. Kiken LG, Shook NJ. Mindfulness and emotional distress: The role of negatively biased cognition. Pers Individ Dif 2012;52:329-33. https://doi.org/10.1016/j. paid.2011.10.031.

60. Dobkin PL, Hutchinson TA. Teaching mindfulness in medical school: Where are we now and where are we going? Med Educ 2013;47:768-79. https://doi. org/10.1111/medu.12200.

61. Hassed C, De Lisle S, Sullivan G, Pier C. Enhancing the health of medical students: Outcomes of an integrated mindfulness and lifestyle program. Adv Heal Sci Educ 2009;14:387-98. https://doi.org/10.1007/s10459-0089125-3.

62. Krasner MS, Epstein RM, Beckman H, Suchman $\mathrm{AL}$, Chapman B, Mooney CJ, et al. Association of an educational program in mindful communication with burnout, empathy, and attitudes among primary care physicians. JAMA 2009;302:1284-93. https://doi. org/10.1001/jama.2009.1384.

63. Frank JR, Snell LS, Sherbino J. The draft CanMEDS 2015 physician competency framework. 2015. https:// doi.org/10.13140/2.1.5039.4402. 